\title{
Reversible 0-O bond cleavage in copper-dioxygen isomers: impact of anion basicity
}

\author{
Xavier Ottenwaelder, Deanne Jackson Rudd, Mary C. Corbett, Keith O. Hodgson, Britt \\ Hedman, and T. Daniel P. Stack \\ Department of Chemistry, Stanford University, Stanford, CA 94305 and Stanford Synchrotron \\ Radiation Laboratory, SLAC, Stanford, CA 94309
}

$\mu-\eta^{2}: \eta^{2}$-peroxodicopper(II) (P) and bis $(\mu-$ oxo)dicopper(III) (O) complexes are valence isomers that differ by the degree of $\mathrm{O}_{2}$ reduction and the presence of an $\mathrm{O}-\mathrm{O}$ bond. ${ }^{1,2}$ These isomers can exist in a measurable equilibrium with a small activation energy. ${ }^{3-6}$ This facile isomerization is significant to the processes of making and breaking an $\mathrm{O}-\mathrm{O}$ bond, which are key steps in photosynthesis, respiration, and the catalytic cycle of tyrosinase, a binuclear copper enzyme that ortho-hydroxylates phenols. The characterized $\mathbf{P}$ species of oxygenated tyrosinase is accepted as the active oxidant in the oxygen atom transfer reaction, but a transient $\mathbf{O}$-type species in which the $\mathrm{O}-\mathrm{O}$ bond is cleaved prior to oxygen insertion cannot be overlooked. ${ }^{7}$ Understanding these steps in detail is important to the design of synthetic catalysts that use $\mathrm{O}_{2}$ as a terminal oxidant.

A systematic study of the influence of the Lewis basicity of various anions, i.e. their coordinating ability, on the $\mathbf{P} / \mathbf{O}$ equilibrium was undertaken as a model of substrate binding to the $\mathbf{P}$ core in tyrosinase. ${ }^{5,6} \mathbf{P} / \mathbf{O}$ mixtures were prepared with the ligand $N, N, N^{\prime}, N^{\prime}-$ tetraethylpropane-1,3-diamine (TEPD) by injecting a $\mathrm{CH}_{2} \mathrm{Cl}_{2}$ solution of [(TEPD) $\mathrm{Cu}$ $\left.\left(\mathrm{CH}_{3} \mathrm{CN}\right)_{n}\right](\mathrm{X})$, where $\mathrm{X}^{-}=\mathrm{SbF}_{6}^{-}, \mathrm{CF}_{3} \mathrm{SO}_{3}{ }^{-}, \mathrm{TsO}^{-}$( $p$-toluenesulfonate) or $\mathrm{CH}_{3} \mathrm{SO}_{3}{ }^{-,} 8$ into a precooled, preoxygenated volume of $\mathrm{CH}_{2} \mathrm{Cl}_{2}$, tetrahydrofuran (THF) or acetone $\left(-85^{\circ} \mathrm{C}, 1\right.$ atm $\mathrm{O}_{2}, 1 \mathrm{mM}$ in $\mathrm{Cu}$ ). $\mathbf{P}$ and $\mathbf{O}$ isomers were stable only below $-75^{\circ} \mathrm{C}$ and were identified by their characteristic charge-transfer absorptions (Table 1, Figure 1). ${ }^{1}$ In THF or $\mathrm{CH}_{2} \mathrm{Cl}_{2}$, [(TEPD $\left.)_{2} \mathrm{Cu}_{2} \mathrm{O}_{2}\right]\left(\mathrm{CF}_{3} \mathrm{SO}_{3}\right)_{2}$ exhibits rapid, reversible interconversion between equilibrium positions upon temperature change. ${ }^{9}$ A Van't Hoff analysis yields $\Delta H^{\circ}=-4.3(2) \mathrm{kJ} \mathrm{mol}^{-1}$ and $\Delta S^{\circ}=-24(2) \mathrm{J} \mathrm{K}^{-1} \mathrm{~mol}^{-1}$ for this $\mathbf{P} \Leftrightarrow \mathbf{O}$ equilibrium in THF: $\mathbf{O}$ is favored enthalpically and $\mathbf{P}$ is favored entropically, as previously determined for other systems. 4,5

More strongly coordinating counteranions bias the $\mathbf{P}: \mathbf{O}$ equilibrium position towards $\mathbf{P}$, from $\sim$ 10:90 with $\mathrm{SbF}_{6}{ }^{-}$to $\sim 100: 0$ with $\mathrm{CH}_{3} \mathrm{SO}_{3}{ }^{-}$(Figure 1a). The $\mathbf{P : O}$ ratio follows anion basicity regardless of size: e.g. $\mathrm{CH}_{3} \mathrm{SO}_{3}{ }^{-}$is slightly smaller than $\mathrm{CF}_{3} \mathrm{SO}_{3}{ }^{-}$, yet the more compact $\mathbf{O}$ isomer is not observed with $\mathrm{CH}_{3} \mathrm{SO}_{3}^{-}$. Such a basicity effect is counter-intuitive, as more electron donation to the $\mathrm{Cu}_{2} \mathrm{O}_{2}$ core is anticipated to stabilize the higher oxidation state of the copper centers and hence favor the $\mathbf{O}$ isomer. ${ }^{10}$

Titration experiments with competing anions highlight the importance of anion basicity and reveal the existence of specific anion/dication interactions. Addition of a more coordinating anion $\mathrm{Y}^{-}\left(\mathrm{CF}_{3} \mathrm{SO}_{3}^{-}, \mathrm{TsO}^{-}, \mathrm{CH}_{3} \mathrm{SO}_{3}^{-}, \mathrm{CF}_{3} \mathrm{CO}_{2}^{-}, \mathrm{PhCO}_{2}{ }^{-}\right)$to a preformed $\mathbf{P} / \mathbf{O}$ solution with a "weaker" anion $\mathrm{X}^{-}\left(\mathrm{SbF}_{6}{ }^{-}, \mathrm{CF}_{3} \mathrm{SO}_{3}{ }^{-}\right)$results in a rapid, isosbestic isomerization in the direction $\mathbf{O} \rightarrow \mathbf{P}$. Spectroscopically pure $\mathbf{P}$ species are obtained by addition of 1.0 equivalent of $\mathrm{TsO}^{-}, \mathrm{CH}_{3} \mathrm{SO}_{3}^{-}, \mathrm{CF}_{3} \mathrm{CO}_{2}^{-}$or $\mathrm{PhCO}_{2}^{-}$per binuclear complex (Figure $1 \mathrm{~b}$ ). ${ }^{6,11} \mathrm{In}$ all cases, no significant spectral changes occur upon addition of more than 1.0 equivalent of $\mathrm{Y}^{-}$per $\mathrm{Cu}_{2} \mathrm{O}_{2}$ species, and the final $\mathbf{P : O}$ ratio is the same as per direct oxygenation of [(TEPD) $\mathrm{Cu}$ $\left.\left(\mathrm{CH}_{3} \mathrm{CN}\right)_{n}\right](\mathrm{Y})\left(\mathrm{Y}^{-}=\mathrm{CF}_{3} \mathrm{SO}_{3}{ }^{-}, \mathrm{TsO}^{-}\right.$or $\left.\mathrm{CH}_{3} \mathrm{SO}_{3}{ }^{-}\right)$. In contrast, the reverse titration of a 
[(TEPD $\left.)_{2} \mathrm{Cu}_{2} \mathrm{O}_{2}\right](\mathrm{Y})_{2}$ solution with a "weaker" $\mathrm{X}^{-}$anion is incomplete even with 200 equivalents of $\mathrm{X}^{-}$per dimer. ${ }^{12}$ Overall, these experiments suggest that each dicationic $\mathrm{Cu}_{2} \mathrm{O}_{2}$ species is associated with one anion intimately. ${ }^{13}$

Extended X-ray Absorption Fine Structure (EXAFS) analysis of a frozen THF solution of [(TEPD $\left.)_{2} \mathrm{Cu}_{2} \mathrm{O}_{2}\right]\left(\mathrm{CH}_{3} \mathrm{SO}_{3}\right)_{2}$ provides structural evidence of the close association between the anion and the $\mathrm{Cu}_{2} \mathrm{O}_{2}$ core in this spectroscopically pure $\mathbf{P}$ species. The EXAFS data are consistent with a side-on peroxo-bridged copper dimer having four $\mathrm{Cu}-\mathrm{N} / \mathrm{O}^{14}$ interactions at $1.94 \AA$, one $\mathrm{Cu}-\mathrm{O}$ at $2.26 \AA$, and one $\mathrm{Cu} \cdots \mathrm{Cu}$ at $3.51 \AA$ (Figure $2 \mathrm{a}) .{ }^{1}$ The scattering atom at $2.26 \AA$ is required for a good fit and is ascribed to a $\mathrm{CH}_{3} \mathrm{SO}_{3}{ }^{-}$oxygen atom, ${ }^{15}$ consistent with the titration experiments. Coordination of $\mathrm{CH}_{3} \mathrm{SO}_{3}{ }^{-}$would place the sulfur atom within 3.3$3.8 \AA$ of the copper centers, which corresponds to the poorly fitted region in the 4-component model. A 5-component EXAFS fit with a $\mathrm{Cu} \cdots \mathrm{S}$ interaction at a refined distance of $3.47 \AA^{16}$ provides a better match to the data (Figure $2 b$, Table $S 1$ ). The dual requirement for a $\mathrm{Cu}-\mathrm{O}$ interaction at $2.26 \AA$ and a $\mathrm{Cu} \cdots \mathrm{S}$ interaction at $3.47 \AA$ in the EXAFS fit establishes that the $\mathrm{CH}_{3} \mathrm{SO}_{3}{ }^{-}$anion is well-ordered at close range from the $\mathrm{Cu}_{2} \mathrm{O}_{2}$ core.

Density Functional Theory (DFT) calculations ${ }^{17}$ support the EXAFS structure. A plausible model consists of the association between a $\left[(\mathrm{TEPD})_{2} \mathrm{Cu}_{2} \mathrm{O}_{2}\right]^{2+}$ molecule and one $\mathrm{CH}_{3} \mathrm{SO}_{3}{ }^{-}$ anion, in accord with the experimental 1:1 anion-to-dimer stoichiometry. Electronic

optimization of this model with a $\mathrm{Cu} \cdots \mathrm{Cu}$ distance fixed to the experimental value of $3.51 \AA$ converges to the $\mathbf{P}$ species depicted in Figure 3. The $\mathrm{CH}_{3} \mathrm{SO}_{3}{ }^{-}$anion bridges the two copper (II) ions through axial positions, a ligation mode documented for the weaker triflate anion in copper dimers. ${ }^{18}$ The calculated distances about the copper ions agree closely with the EXAFS results, notably for the axial oxygen atoms. The $\mathrm{Cu}_{2} \mathrm{O}_{2}$ core exhibits a slight butterfly distortion with a dihedral angle of $\sim 150^{\circ}$ between the two $\mathrm{CuO}_{2}$ planes that may account for the weak feature at $\sim 500 \mathrm{~nm}$ in the UV-Vis spectrum of this $\mathbf{P}$ species (Figure 1a). ${ }^{19}$

The axial ligation mode of the anion is substantiated experimentally. The $\sim 600 \mathrm{~nm}$ chargetransfer feature of the $\mathbf{P}$ isomers shifts to lower energies by $12 \%$ as the basicity of the counteranion increases from $\mathrm{CF}_{3} \mathrm{SO}_{3}{ }^{-}$to $\mathrm{PhCO}_{2}^{-}$(Table 1). Since this transition originates from the out-of-plane $\pi^{*}$ orbital of the peroxo moiety, this large shift strongly suggests that the anion is positioned above the $\mathrm{Cu}_{2} \mathrm{O}_{2}$ plane. This indirect characterization of the anion-core association may become useful for probing substrate binding to a $\mathbf{P}$ core.

In conclusion, axial binding of an anion induces an electronic/electrostatic, not steric, preference for the $\mathbf{P}$ isomer: the $\mathrm{O}-\mathrm{O}$ bond is not cleaved with an anion positioned axially on the $\mathrm{Cu}$ centers. In oxytyrosinase, although the substrate presumably approaches the $\mathbf{P}$ core from above, ${ }^{20}$ its subsequent deprotonation yields a phenolate anion, which is much more basic than the anions used here. Such a strong ligand can potentially redefine the equatorial planes of the copper centers with minimal reorganization of the $\mathrm{O}_{2}$-derived ligands. Such change could trigger $\mathrm{O}-\mathrm{O}$ bond cleavage and yield a reactive $\mathbf{O}$-type species, as suggested recently. ${ }^{7}$

\section{Supplementary Material}

Refer to Web version on PubMed Central for supplementary material.

\section{Acknowledgements}

Grants from the NIH are gratefully acknowledged: GM-50730 (T.D.P.S.) and RR-01209 (K.O.H.). The SSRL is supported by the DOE-BES and the SSRL XAS facilities by DOE-BER and NIH-NCRR-BTP. 


\section{References}

1. Mirica LM, Ottenwaelder X, Stack TDP. Chem Rev 2004;104:1013-1045. [PubMed: 14871148]

2. Lewis EA, Tolman WB. Chem Rev 2004;104:1047-1076. [PubMed: 14871149]

3. Halfen JA, Mahapatra S, Wilkinson EC, Kaderli S, Young VG, Que L Jr, Zuberbühler AD, Tolman WB. Science 1996;271:1397-1400. [PubMed: 8596910]Henson MJ, Vance MA, Zhang CX, Liang HC, Karlin KD, Solomon EI. J Am Chem Soc 2003;125:5186-5192. [PubMed: 12708870]

4. Cahoy J, Holland PL, Tolman WB. Inorg Chem 1999;38:2161-2168. [PubMed: 11671001]Liang HC, Henson MJ, Hatcher LQ, Vance MA, Zhang CX, Lahti D, Kaderli S, Sommer RD, Rheingold AL, Zuberbuhler AD, Solomon EI, Karlin KD. Inorg Chem 2004;43:4115-4117. [PubMed: 15236520]

5. Mahadevan V, Henson MJ, Solomon EI, Stack TDP. J Am Chem Soc 2000;122:10249-10250.

6. Stack TDP. Dalton Trans 2003;10:1881-1889.

7. Mirica LM, Vance M, Jackson Rudd D, Hedman B, Hodgson KO, Solomon EI, Stack TDP. Science 2005;308:1890-1892. [PubMed: 15976297]

8. The 1:1 TEPD-Cu complex is prepared in a drybox by mixing equimolar amounts of TEPD and [Cu $\left.\left(\mathrm{CH}_{3} \mathrm{CN}\right)_{n}\right](\mathrm{X})(\mathrm{n}=3,3.5$, or 4$)$ in $\mathrm{CH}_{2} \mathrm{Cl}_{2}$. This clear, colorless solution is used directly. The salts $\left[\mathrm{Cu}\left(\mathrm{CH}_{3} \mathrm{CN}\right)_{3}\right](\mathrm{TsO})$ and $\left[\mathrm{Cu}\left(\mathrm{CH}_{3} \mathrm{CN}\right)_{3.5}\right]\left(\mathrm{CH}_{3} \mathrm{SO}_{3}\right)$ were prepared by adapting the procedure ofKubas GJ, Monzyk B, Crumbliss AL. Inorg Synth 1979;19:90-92.

9. In cases where the P:O ratio differs significantly from 1:1, the equilibrium presumably occurs, but is difficult to detect due to the predominance of one isomer and the broadness of the UV-Vis features.

10. Hatcher LQ, Vance MA, Sarjeant AAN, Solomon EI, Karlin KD. Inorg Chem 2006;45:3004-3013. [PubMed: 16562956]

11. Strong anions are detrimental to the stability of the $\mathrm{Cu}_{2} \mathrm{O}_{2}$ species. The use of $\mathrm{PhCO}_{2}{ }^{-}$was successful only in acetone at $-87^{\circ} \mathrm{C}$ with slow addition of up to 1.0 equivalent of anion per dimer. The acetate anion behaves similarly, but its $\mathbf{P}$ species is too unstable to allow a complete titration.

12. The $\mathbf{P : O}$ ratio is fairly insensitive to ionic strength: only $10 \%$ of the total $\mathrm{Cu}_{2} \mathrm{O}_{2}$ concentration is converted from $\mathbf{P}$ to $\mathbf{O}$ with 200 equivalents of $\mathrm{CF}_{3} \mathrm{SO}_{3}{ }^{-}$added per [(TEPD) $\left.)_{2} \mathrm{Cu}_{2} \mathrm{O}_{2}\right]\left(\mathrm{CF}_{3} \mathrm{SO}_{3}\right)_{2}(\mathrm{cf}$. supporting information).

13. The $\mathbf{P : O}$ ratios of $\left[(\mathrm{TEPD})_{2} \mathrm{Cu}_{2} \mathrm{O}_{2}\right](\mathrm{X})_{2}\left(\mathrm{X}^{-}=\mathrm{SbF}_{6}{ }^{-}\right.$or $\left.\mathrm{CF}_{3} \mathrm{SO}_{3}{ }^{-}\right)$in the more polar solvent acetone are consistently $<10: 90$, suggesting that anion association is weak in these cases. The more basic $\mathrm{TsO}^{-}$and $\mathrm{CH}_{3} \mathrm{SO}_{3}{ }^{-}$anions yield solutions of the same composition in all three solvents, suggesting that they form an intimate association with the $\mathrm{Cu}_{2} \mathrm{O}_{2}$ species.

14. Scatterers differing by $\mathrm{Z} \pm 1$ are not distinguishable in an EXAFS analysis. For this data, the resolution of such scatterers is $\sim 0.12 \AA$.

15. Mahadevan V, Dubois JL, Hedman B, Hodgson KO, Stack TDP. J Am Chem Soc 1999;121:55835584.

16. $\mathrm{Cu} \cdots \mathrm{S}$ scattering at $3.4 \AA$ has the same frequency but opposite phase as $\mathrm{Cu} \cdots \mathrm{Cu}$ scattering at $3.5 \AA$. This coincidence prevents independent determination of these two components. Therefore, their $\sigma^{2}$ parameters were constrained to have equal values during refinement.

17. DFT optimizations were performed in vacuo with a B3LYP function, a 6-31G* basis set, and a brokensymmetry wavefunction for the singlet ground state.

18. Van Albada GA, Mutikainen I, Turpeinen U, Reedijk J. Inorg Chim Acta 2001;324:273-277.Van Albada GA, Smeets WJJ, Spek AL, Reedijk J. Inorg Chim Acta 1997;260:151-161.Dedert PL, Sorrell T, Marks TJ, Ibers JA. Inorg Chem 1982;21:3506-3517.

19. Pidcock E, Obias HV, Abe M, Liang HC, Karlin KD, Solomon EI. J Am Chem Soc 1999;121:1299_ 1308.

20. Matoba Y, Kumagai T, Yamamoto A, Yoshitsu H, Sugiyama M. J Biol Chem 2006;281:8981-8990. [PubMed: 16436386] 

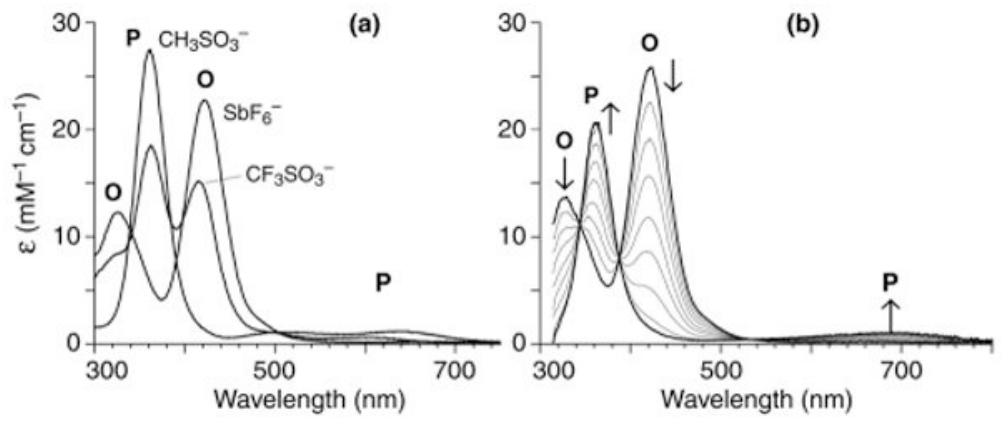

Figure 1.

(a) UV-Vis spectra of $\left[(\mathrm{TEPD})_{2} \mathrm{Cu}_{2} \mathrm{O}_{2}\right](\mathrm{X})_{2}$, with $\mathrm{X}^{-}=\mathrm{SbF}_{6}{ }^{-}, \mathrm{CF}_{3} \mathrm{SO}_{3}{ }^{-}$and $\mathrm{CH}_{3} \mathrm{SO}_{3}{ }^{-}$in $\mathrm{THF}$ at $-85^{\circ} \mathrm{C}$. (b) Addition of $\left[\mathrm{N}(n-\mathrm{Bu})_{4}\right]\left(\mathrm{PhCO}_{2}\right)(0-0.9$ equivalent per dicopper species $)$ to an acetone solution of $\left[(\mathrm{TEPD})_{2} \mathrm{Cu}_{2} \mathrm{O}_{2}\right]\left(\mathrm{CF}_{3} \mathrm{SO}_{3}\right)_{2}$ at $-87^{\circ} \mathrm{C}$. 11 

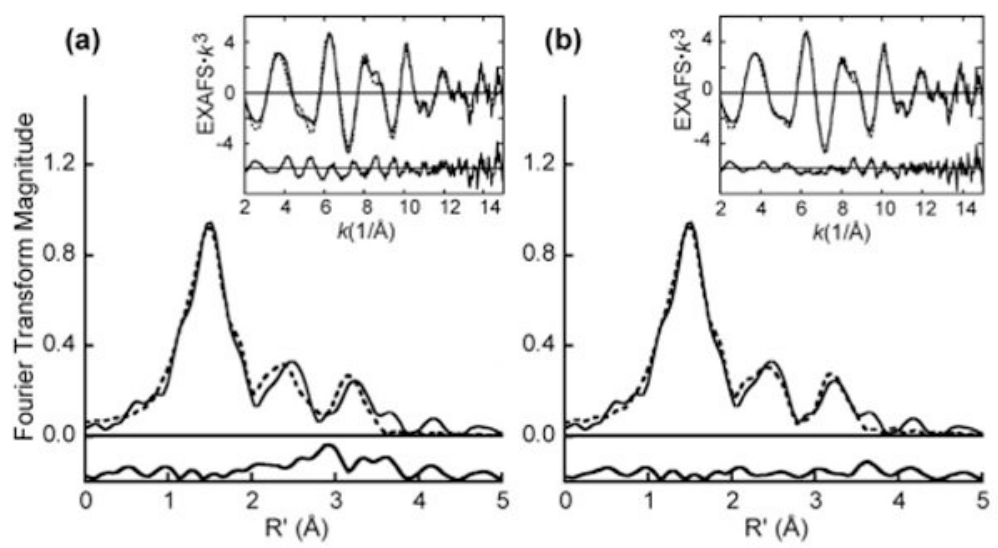

Figure 2.

EXAFS data (inset) and Fourier transforms with offset fit residuals (bottom) of $\left[(\mathrm{TEPD})_{2} \mathrm{Cu}_{2} \mathrm{O}_{2}\right]\left(\mathrm{CH}_{3} \mathrm{SO}_{3}\right)_{2}$ (-). (a) 4-component fit (- - ); (b) 5-component fit (- - -): $4 \mathrm{Cu}-$ $\mathrm{N} / \mathrm{O}=1.94 \AA, 1 \mathrm{Cu}-\mathrm{O}=2.26 \AA, 6 \mathrm{Cu} \cdots \mathrm{C}=2.88 \AA, 1 \mathrm{Cu} \cdots \mathrm{S}=3.47 \AA, 1 \mathrm{Cu} \cdots \mathrm{Cu}=3.51 \AA$. 


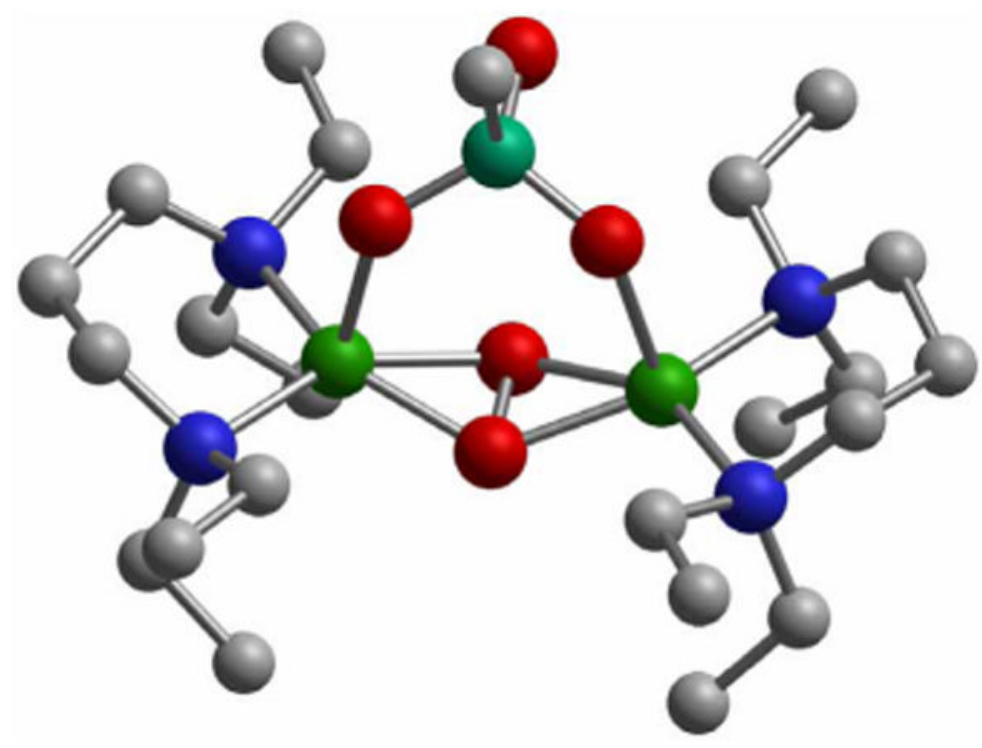

Figure 3.

DFT-optimized geometry of $\left\{\left[(\mathrm{TEPD})_{2} \mathrm{Cu}_{2} \mathrm{O}_{2}\right]\left(\mathrm{CH}_{3} \mathrm{SO}_{3}\right)\right\}^{+}$. $\mathrm{Cu}-\mathrm{O}_{\mathrm{eq}}=1.94 \AA$ (avg), $\mathrm{Cu}-\mathrm{N}$ $=2.02 \AA(\mathrm{avg}), \mathrm{Cu}-\mathrm{O}_{\mathrm{ax}}=2.26 \AA, \mathrm{Cu} \cdots \mathrm{C}=2.87 \AA(\mathrm{avg}), \mathrm{Cu} \cdots \mathrm{S}=3.36 \AA$ and $\mathrm{Cu} \cdots \mathrm{Cu}$ fixed to $3.51 \AA$. 


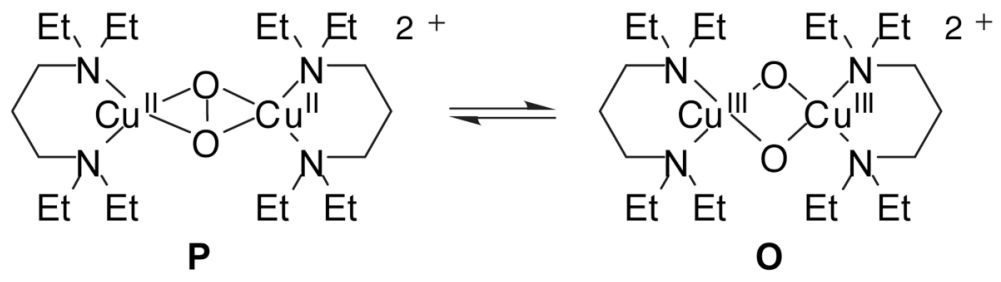

Scheme 1.

Equilibrium between TEPD-based $\mathbf{P}$ and $\mathbf{O}$ species 


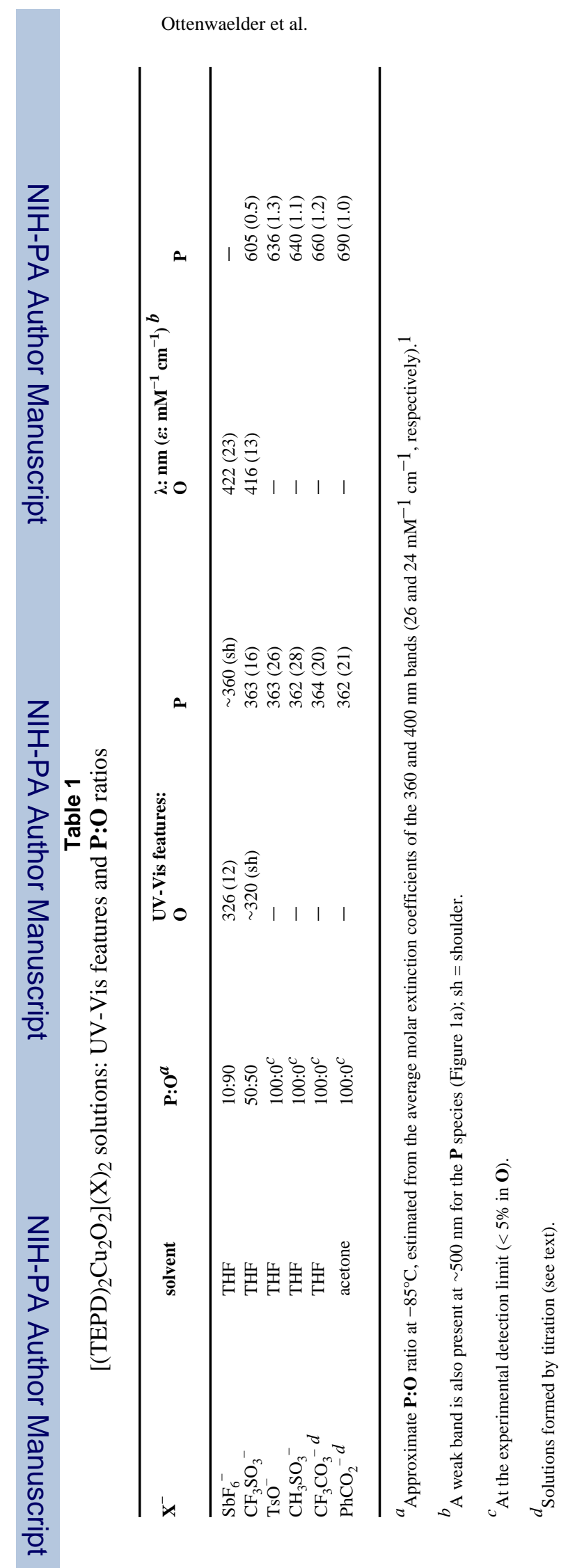

Page 8 